\title{
State Shari'a and Its Limits
}

\author{
R. Michael Feener
}

Aceh has experienced dramatic social change over the past decade, with devastating natural disaster followed by unprecedentedly ambitious projects of reconstruction and development. ${ }^{1}$ The shock of this unforeseen tragedy redefined priorities, transformed conversations about the future of Acehnese society, and accelerated ongoing negotiations to bring an end to armed conflict in the region. The peace agreement was formally concluded in July 2005 at Helsinki, bringing to an end decades of violent struggle between the Indonesian central government and the Free Aceh Movement (Gerakan Aceh Merde$\mathrm{ka} / \mathrm{GAM}$ ). These developments contributed to the establishment of a level of stability that allowed for attention to be refocused on issues of social order under a civilian administration - which in turn set the stage for a reworking of the earlier special autonomy measures that provided for the state implementation of Islamic law. It also greatly facilitated the work of international development agencies and NGOs to carry out massive projects of reconstruction in Aceh. Consequently, enormous amounts of money flowed in, allowing a range of international NGos to field-test their latest theories of linking disaster relief and recovery with longer-term, future-oriented development projects.

Under the popular motto of "Building Back Better," reconstruction in Aceh looked beyond purely physical rebuilding to include also a broad range of programs aimed at the improvement of economic and social conditions. This ambitious constellation of projects aimed not only to manage the reconstruction of homes and physical infrastructure in disaster-affected areas, but also to construct and implement new models of quality assurance, transparency, good governance, and gender equity in post-tsunami Aceh. Well beyond the

1 Research for this chapter was undertaken partially with the support of the Singapore Ministry of Education's Academic Research Fund (MoE AcRF \# R-110-00o-029-750). I would like to thank Mahdi Abdullah Syihab for his invaluable assistance in collecting some of the primary materials consulted for this study, as well as Prasenjit Duara, Ben Arps, Julius Bautista, Philip Fountain, Arif Jamal, Jeremy Kingsley, Deepa Nair, Liang Yongjia, Yijiang Zhong, Annemarie Samuels, David Kloos, and all the participants at the Leiden workshop for their critical comments on earlier drafts of this chapter. 
specific projects of the state, international development organizations, and NGOs, Acehnese public discourse became saturated with ideals and idioms of 'improvement' during the post-tsunami/post-conflict period. In fields ranging from physical infrastructure to Islamic law, there developed an expansive vision of 'total reconstruction' that would remake Aceh literally 'from the ground up.'2 Combined with the euphoric discourses surrounding the dawn of a new peace, in a region long plagued by violent conflict, reconstruction projects fostered the emergence of possibilities for creating a 'new Aceh' that would transform the lives of a people who had suffered so much war and devastation.

As Annemarie Samuels (2012) has demonstrated, the higher-level policy discussions of reconstruction and economic development were elaborated within more diffuse projects of the 'remaking of everyday life.' In her contribution to this volume, she turns attention to the diverse narratives of 'improvement' that have been developed and deployed by individuals in Aceh to help them explain and understand the tragedy. These processes involved some significant reconfigurations of local understandings of Islam, including its place within the personal experience of individuals in relation to broader aspects of social life. These diverse experiences and interpretations of Islam in contemporary Aceh continue to draw on a rich and complex constellation of traditions, growing out of the region's historical religious and cultural legacies. This volume aims to open a set of windows on to these developments through studies highlighting the diversity of ways in which Muslims in Aceh have worked to negotiate these dramatic social transformations. The importance here lies not only in a richer empirical picture of recent developments there, but also in helping to develop a more nuanced critical perspective on relations between Islamic doctrine and practice, official government institutions, civil society organizations, and the experiences of individual Muslims in local communities. This move to provide a more diverse and complex matrix of understandings and experiences within which to contextualize the provincial government's project of Shari'a social engineering is what we intend here by the idea of looking at Islam 'beyond the limits of the state."

The contributors to this volume pursue this idea through a series of ethnographic explorations of cases ranging from NGOS and diaspora politics to female ulama and punk rockers. In order to provide some broader contexts for these discussions, this introductory essay will begin with an historical overview

2 For more on the processes of reconstruction, see Daly, Feener, and Reid (2012).

3 The overview of Aceh's state Shari'a system presented on the pages that follow uses material drawn from my recent monograph on the subject (Feener 2013). More extensive discussions of particular points and full citations to primary source material can be found there. 
of Islam in Aceh, with a focus on those aspects that have significantly informed the contemporary cases presented in the chapters that follow. ${ }^{4}$

\section{Aceh's Historical Legacies as an 'Abode of Islam'}

The northern tip of Sumatra has been home to some of the earliest Muslim port polities in the Indonesian Archipelago. From the late thirteenth century, their courts patronized Islamic scholars and Sufis from across the Islamic world; and they brought with them diverse models of belief and practice that have left a continuing imprint on the subsequent development of Islam in Aceh. In the seventeenth century, the court of Aceh's sultans was the site of pronounced competition between different forms of Sufism, as their proponents competed for royal favour. With the waning of the sultanate's power and control over its once extensive domains in the eighteenth century, new forms of Islam made inroads, resulting in further reconfigurations-particularly with regard to the development of Sufi orders beyond the circles of the court. During the nineteenth century, local Muslim leaders drawing on aspects of these traditions of Sufism emerged to mobilize resistance to the incursion of the Dutch. The Dutch launched their first invasion of Aceh in 1873, in response to which the Acehnese waged a long war of anti-colonial resistance cast in terms of a jihad in the defence of Islam against invading infidels. Calls for these campaigns of resistance drew on the traditions of activist Sufism that had taken root in the region over the course of the eighteenth and early nineteenth centuries-including the Sumatran scholar 'Abd al-Samad al-Palimbani (al-Jawi)'s treatise on jihad. ${ }^{5}$ Over the late nineteenth century, these ideas of Islamic mysticism and militant mobilization came to be expressed through a new genre of 'holy war' texts in Acehnese verse, generally referred to as Hikayat Prang Sabi. ${ }^{6}$

4 For a more extensive introduction to major developments in, and sources for, the history of Islam in Aceh, see Feener (2011).

5 One early exemplar of the Acehnese genre of 'Holy War' texts-Nya' Ahmat's 1894 exhortation to jihad against the incursion of the Dutch entitled Nasihat ureueng muprang-draws on the work of Palimbani's Nasihat al-muslimin wa tadhkirat al-mu'minun fi fada'il al-jihad fi sabil Allah (Snouck Hurgronje 1906: II, 119). For more on 'Palimbani,' see: Feener (2015).

6 There is a considerable body of modern writing on Acehnese Prang Sabi texts-and in fact this particular genre of texts has received attention disproportionate to its place within the broader tradition of Acehnese literature. See, for example: Alfian (2006, 109-120); Amirul Hadi (2011, 183-198); and Damsté (1928, 545-6o9). 
By the early decades of the twentieth century, however, the Dutch colonial state had consolidated its control over Aceh, while local ulama also came to solidify their own autonomous institutional foundations in the form of educational institutions known in Acehnese as dayah. These Islamic religious boarding schools came to serve as the primary organizational structures of Islam in Aceh in the early twentieth century and provided the ulama with avenues of considerable social influence in particular local communities. The forms of Islam promoted within Acehnese dayah were diverse, but there did emerge a broad general tendency for most to share traditions of Shafici jurisprudence ( figh) and Khalidi-Naqshbandi Sufism. ${ }^{7}$ These traditional modes of Islamic belief and practice were, however, at the same time becoming the object of sharp critiques by a new generation of modernist reformers associated with a new style of madrasa schools spreading through the region. These modern reformers drew on discourses that articulated new visions of Islam that were then developing in the Middle East and South Asia, in which the Sharia was envisioned as serving as the foundation for a thorough reconstitution of society (Siegel 1969, 98-133).

In Aceh, these modernist reformers came to be organized in a new 'union' of ulama known locally as PUSA (Persatuan Ulama Seluruh Aceh, the AllAcehnese Organization of Ulama), which was largely concentrated in the area surrounding Banda Aceh and in the towns along Aceh's north coast. PUSA's leadership was often antagonistic toward aspects of Acehnese tradition, and its members aggressively critiqued a range of customary practices that had come to be associated with Islam as blameworthy 'innovations' that had to be suppressed. Many of them were also stridently opposed to the forms of Sufism that had become so widely established in Aceh at that time. These stark positions on prominent expressions of Islam contributed to tensions between 'modernist' and 'traditionalist' Muslims in Aceh, which took the form of political struggles and even violent conflict during the early years of Indonesian independence. In ways not unlike that of the PUSA Modernists, Aceh's traditionalist ulama also mobilized themselves into organizations including a militia named the Barisan Hizbullah and a political party called PERTI (Persatuan Tarbiyah Islamijah), which was led by Teungku Muda Waly in South Aceh. ${ }^{8}$

7 This sub-tradition of the Naqshbandiyya traces its origins to Iraq and the teachings of Shaykh Khalid al-Kurdi (d. 1827). For more on its introduction to and development in Indonesia, see Kraus (1990); van Bruinessen (2007).

8 An introduction to PERTI and an overview of the development of its politics can be found in Koto (1997). For more on the PERTI political activism of Muda Waly in particular, see van Bruinessen (1992, 143-146). 
It was PUSA, however, that was most successful in establishing itself as the dominant Islamic organization in Aceh at mid-century. This ascendency was aided, in part, by the role of some of PUSA's leadership in collaborating with the Japanese during their wartime occupation of Sumatra (1942-1945). Under the Japanese occupation, PUSA was able to claim important positions within the new structures of state authority. The relationship of PUSA with the Japanese occupational forces was, however, a complex one and the ulama were not the only beneficiaries of new policies under the Japanese military administration. Like the Dutch before them, the Japanese pursued strategies that played off the divisions between the ulama and the local landed aristocracy (uleebalang) in ways that served to strengthen their control over Aceh. In this way, the policies of the Japanese occupation maintained and deepened local divisions and rivalries among the Acehnese over issues of religious and political authority (Shiraishi 1975, 33-35).

\section{Aceh, Islam, and Independent Indonesia}

At the end of the war, PUSA moved swiftly against their primary political rivals, the uleebalang, who were now branded as the last remaining allies of the fallen Dutch colonial order. From December 1945 to January 1946, violent clashes erupted across Aceh, in what came to be known as the 'Social Revolution' (Revolusi Sosial). By the end of it, most of the uleebalang in the crucial districts of Pidie and North Aceh were killed, and many of those who survived fled from Aceh-thereby leaving the former power of the uleebalang much diminished (Reid 1979). This left the field open for a reconstitution of a professional administrative class in Aceh, the ranks of whom soon swelled with young Muslim professionals with allegiance to PUSA. At the forefront of this new ascendency of Aceh's Modernist Muslims was PUSA's charismatic leader, Daud Beureueh, who emerged from the war not only as Aceh's foremost Islamic reformist leader, but also as its military governor and chief administrator. PUSA affiliates thus came to dominate many sectors of the civil administration in post-war Aceh. With Daud Beureueh at its head, PUSA capitalized on their newly privileged position in society to energetically promote its vision of Islam in the making of a new, modern Aceh. ${ }^{9}$ This included the expansion of the jurisdiction of the Sharia

9 This included a stepping up of its earlier campaigns against customary practices. See for example, the 1948 PUSA proclamation on Traditionalist funerary practices, recently reprinted in Analiansyah and Jamhuri (2008, 4-5). 
courts and attempts at promoting new legislation governing aspects of public morality including gambling, alcohol consumption, and relations between the sexes. ${ }^{10}$

PUSA's position of dominance was, however, significantly compromised when the Indonesian central government moved to consolidate control over the country by dissolving the province of Aceh and annexing its territory to the neighbouring province of North Sumatra, with its capital in Medan. PUSA's reactions to this loss of control over local administration, together with a complex of other social and economic factors, ultimately culminated in the declaration of armed opposition to the central Indonesian state in 1953 (Feith 1962, 345-346). This rebellion against the Republic of Indonesia was referred to as the 'Darul Islam' ('Abode of Islam') movement, and it came to be linked together with other armed campaigns under that name for the establishment of an 'Islamic state' of Indonesia (Formichi 2012, 109-243; van Dijk 1981, 309336). The Darul Islam movement in Aceh waged a long struggle to establish a modern Islamic state, but it was ultimately unsuccessful. Agreements to end hostilities were reached with most of the rebel leaders in 1959, when Aceh was granted the status of a 'special' province with concessions of autonomy in the fields of religion, customary law (adat) and education.

After the formal end of the Darul Islam revolt, the next major political and social transformations for Aceh came in the wake of the collapse of Soekarno's founding regime of the Indonesian Republic and the establishment of Suharto's New Order in 1965. At that time, the dynamics of interaction between Aceh and the Indonesian central government underwent a new evolution, including a reframing of visions of the role of Islam in defining Acehnese identity in official discourse. The most prolific and high-profile figure in producing the New Order narrative of Acehnese Islam was Ali Hasjmy. Hasjmy had been affiliated with PUSA during his youth, but after being 'rehabilitated' in Jakarta, he came to play key roles in the integration of Aceh into the Indonesian New Order state.

Over the course of his career in Aceh, Hasjmy helped form a number of modern Islamic institutions, all designed to garner broader Muslim support for the assertion of Indonesian national control over the province by actively promoting the New Order's emerging developmentalist ideals as being in line with 'proper' understandings of Islam. Working with Islamic religious leaders, he

10 These same core concerns have also been at the center of twenty-first-century Shari'a legislation in Aceh. The historical relations between contemporary qanun and mid-twentiethcentury projects of Islamic religious and social reform are discussed extensively in Feener (2013). 
developed new structures through which they could contribute their authority in support of various government policies and programs, and in which they also saw opportunities to utilize the resources of the state to further their own agendas for the definition and management of Islam in Aceh. During the latter decades of the twentieth century, the administration of Aceh's provincial bureaucracy was largely headed by a class of technocrats who were entrusted not only with the implementation of economic development projects, but also with counteracting rival ideologies that could inspire opposition to the central Indonesian state (Schlegel 1979). Many of these technocrats were themselves descendants of PUSA-affiliated ulama, with strong personal commitments to Islam, but who had also come to feel that they had a significant stake in the consolidation and perpetuation of Aceh's position within the broader Indonesian nation.

These technocrats tended to be viewed by most outside observers as proponents of a developmentalist modernity with agendas of secularization (McDougall 1979). At least some of the technocrats, however, had formed visions of development that incorporated particular understandings of Islam. I have discussed these visions elsewhere in terms of a ' $d a^{\text {' }}$ wa paradigm' that combined ideas of Islamic reform, Indonesian nationalism, and economic development together in powerful new ways (Feener 2013). The connections between $d a^{\prime} w a$ and developmentalism were, however, particularly pronounced in Aceh. In many ways, Aceh can be seen as a kind of social laboratory for New Order experiments with the state management of Islam. These experiments included the establishment of Indonesia's first state Ulama Council in 1965 and the nation's pioneering Faculty of Dakwah, which was established first in 1968 at the Banda Aceh campus of the State Institute for Islamic Studies (I. Institut Agama Islam Negeri/IAIN, presently UIN) and paved the way for similar faculties to develop at other campuses across the country in the 1970s and 1980 .

Institutions of this type have served to emphasize and impress the centrality of Islam to the reform and control of Acehnese society upon civil servants and the Muslim middle class more broadly over the latter years of the New Order period. They were simultaneously Acehnese Muslims with a strong sense of local identity, and participants in broader trends of Islamic revival that had been gaining ground across Indonesia since the 1970s. These sectors of Acehnese society tended to see their interests as congruent with those of the central Indonesian state (Hefner 1993; Platzdasch 2009). In Aceh, their position was at times considerably more complicated during the years of violent conflict between the Indonesian armed forces and the 'Free Aceh Movement' (I. Gerakan Aceh Merdeka/GAM) that started in the 197os and ultimately sur- 
vived the collapse of the New Order to intensify further in the early years of the twenty-first century.

By that time, both Aceh's Islamic religious leaders and the high command of the Indonesian armed forces in the province had come to explicitly link the issue of Shari'a to that of ending the conflict with GAM. It was in these contexts that the basic parameters of Aceh's current state Shari'a system began to take shape. In February 2004, the top Indonesian military officer in the province proclaimed that "whoever supports the Shari'a also supports the extermination of GAM ... because GAM's actions deviate greatly from the Islamic faith." GAM leaders, for their part, retorted that the state implementation of Shari'a was "a plot by the central government to depict the Acehnese as fanatics in the eyes of the outside world" (Aspinall 2009, 207-214). ${ }^{11}$ Critiques of Aceh's state Sharica system as a cynical political ploy have been common among former supporters of GAM and particularly among Acehnese living in the diaspora, as discussed by Antje Missbach in her chapter below. These views have thence become widely echoed in circles of NGO activists and academics, both within Aceh and beyond - thus contributing further dimensions to local debates over the place of the state in the management of Islamic affairs.

At the same time, within Aceh itself many Islamic leaders, and particularly a number of prominent academics associated with the IAIN, actively supported the state implementation of Islamic law as a means of restoring public order and undermining the separatist claims of GAM over the final years of the twentieth century. The motivations of these actors reflect not only the extent to which they may have been beholden to structures of established political power, but also the aspirational appeal of Sharica as a model of divinely ordained justice and a means of addressing worldly needs for security and stability. At the turn of the twenty-first century, Aceh's state Shari'a project prioritized conceptions of personal morality and the modernizing rationalization of individual religious practice that had been characteristic of earlier models of New Order developmentalist $d a^{\prime} w a$ all across Indonesia. These particular formulations of Islam enjoyed a considerable resonance beyond Aceh, and were seen by some supporters of the state Shari'a project, both locally and in Jakarta, as facilitating the re-integration of Aceh into the wider Indonesian nation.

The formal implementation of Islamic law in Aceh progressed particularly slowly during the first years of the project. It was only in the wake of the 2004 tsunami that the state Sharia project made significant advances, building upon aspects of a broader religious revival and rapidly developing dis- 
courses of remaking society in the post-disaster/post-conflict period. Within these contexts the proponents of Aceh's recently-established, but until then little-enforced, Islamic legal system quickly seized the opportunity to promote their languishing Shari'a project as an important part of rebuilding Aceh in the post-conflict/post-tsunami period. The traumatic experiences of natural disaster and the chaos of war gave increased occasion for many Muslims in Aceh to look into their own diverse understandings of Islam as frameworks for negotiating everyday life in a trying world. Combined with a rhetoric of 'total reconstruction,' promoted by the Indonesian state and international development agencies - as well as the euphoric discourses surrounding the dawn of a new peace in a region long-plagued by violent conflict—religious sensibilities contributed to the emergence of a pervasive sense of the possibility of creating a 'new Aceh' that would transform lives in this long-troubled and recently devastated region. At the same time, engagement with diverse aspects of the broader reconstruction project had the effect of bringing Islamic institutions and leadership further into the orbit of the Indonesian state in complex ways. This involved the redefinition of existing governmental institutions, as well as the creation of new ones.

Aceh's contemporary Islamic legal system can thus be seen as a 'high modern' project of promoting ideals of rationalizing religious reform through the educational and coercive apparatus of the state (Scott 1999). At the same time, however, these understandings of Islam and its role in actively promoting particular agendas of social change were far from universal among Muslims in Aceh itself. This is evident, for example, in the considerable dissent expressed in private complaints, public forums, and the popular media. These aspects of contemporary Acehnese discourse on state Shari'a are explored in the chapters that follow by Dina Afrianty, Antje Missbach, Reza Idria, and Benjamin and Jan Michiel Otto.

\section{Aceh's Contemporary State Shari'a System}

Aceh's Islamic legal system is one of the most complex experiments with the state implementation of Islamic law in the contemporary world, as it deals simultaneously with a complex of dramatic social transformations, while attempting to establish a new legal system within the broader constitutional framework of the Indonesian nation-state. ${ }^{12}$ Aceh has, of course, a long and

12 For comparative perspectives on the contemporary Islamic legal systems of Saudi Arabia, Pakistan, Afghanistan, Nigeria, and Sudan, see Vogel (2000); Lau (2006, 2008); Ostien, 
rich history of incorporating aspects of Shari'a within evolving frameworks of pre-colonial Muslim state structures..$^{13}$ The current Islamic legal system is, however, configured in ways that differ significantly from the forms of legal and political structures of earlier periods-particularly with reference to the ways in which Aceh's 'special autonomy' status frames the application of Shari'a there, within the national legal system. ${ }^{14}$

At the turn of the twenty-first century, new 'Special Autonomy' measures were introduced by the Indonesian central government in an attempt to undercut local support for GAM. This made it possible to reform existing institutions for the administration of Islamic law in the province, and also to establish new ones. Law No. 44/1999 formally recognized the 'Special Status of the Province of Aceh Special Region' in the fields of religion, education and adat, and Law No. 18/2001 conferred in principle, broader powers of provincial selfgovernance. These laws established the framework for the development of new substantive Sharia legislation to address issues of religious observance and public morality, as well as other laws defining the new institutions by which Islamic law would be implemented..$^{15}$

Provisions for the state implementation of Islamic law are contained in regional regulations referred to locally as 'qanun:16 Aside from two qanun dealing with the formation of specific Sharia institutions, the first of these new laws passed was Qanun No. 11/2002, which marked a new level of symbolic state engagement with the particulars of Islamic belief and practice by bringing these aspects of religious observance under the rubric of a regional regulation (qanun).${ }^{17}$ In terms of formal law enforcement, however, the most significant of Aceh's current Sharica regulations have been three laws passed in 2003: No. 12

Nasir, and Kogelmann (2005); and Layish and Warburg (2002); and Otto (2010), respectively.

13 On Islamic law and legal institutions in pre-modern Aceh, see Ito (1984); Lombard (1967).

14 For more extensive discussions of the institutions of state Shari'a in Aceh, see Feener (2013).

15 On the political contexts surrounding the initial implementation of Islamic law in contemporary Aceh, see Aspinall (2009); Lindsey et al. (2007); Miller and Feener (2010); Moch. Nur Ichwan (2007).

16 The standard published source for legislation on the implementation of Islamic law in contemporary Aceh is Himpunan Undang-undang, Keputusan Presiden, Peraturan Daerah/ Qanun, Instruksi Gubernur dan Edaran Gubernur berkaitan Pelaksanaan Syari'at Islam, Edisi Ketujuh (Banda Aceh: Dinas Syari'at Islam Aceh, 2009).

17 Peraturan Dearah Provinsi Nanggroe Aceh Darussalam No. 33/2001 tentang Susunan Organisasi dan Tata Kerja Dinas Syariat Islam; and Qanun Provinsi Nanggroe Darussalam No. 10/2002 tentang Peradilan Syariat Islam. 
on the consumption of alcohol, No. 13 on gambling, and No.14 on inappropriate mixing of the sexes (khalwat). As the only new statements on the content of Sharica to be applied in Aceh to date, these have been the focus of much of the formal legal work of the new, or newly reformulated, institutions of Islamic law there. ${ }^{18}$

Aceh's current Shari'a bureaucracy comprises a number of distinct but interrelated bodies. In this system, the State Shari'a Agency (Dinas Syariat Islam/ DSI) performs coordinating functions in working with the other major institutions involved with the implementation of Islamic law in contemporary Aceh: the Shari'a Courts (Mahkamah Syariah/Ms), the 'Ulama' Council (Majelis Permusyawaratan Ulama/MPU), and the 'Shari'a Police' (Wilayatul Hisbah/wH).

The oldest institution of state Shari'a in Aceh is the system of Islamic courts. While there were mechanisms established for the application of Islamic law under the sultanates, the Islamic courts operative in Aceh today trace their history back only to the mid-twentieth century, when they were established by the Japanese during their wartime occupation of Sumatra (1942-1945). Although under the Darul Islam movement in Aceh, these courts laid claim to a broader jurisdiction, over the second half of the twentieth century, Aceh's Islamic Courts generally operated much like those in other parts of Indonesia. Today, the vast majority of the cases before the court continue to be related to divorce, followed in number by inheritance-and these cases are generally decided according to rules and norms commonly found in the decisions of religious courts elsewhere in Indonesia. The number of cases involving gambling, alcohol consumption and khalwat in 2006-2007 have never amounted to a significant portion of the Shari'a Courts' caseload. Since 2008, there has moreover been an overall decrease in the number of such cases appearing before Aceh's Islamic Courts.

Another previously existing institution for the state regulation of Islamic affairs that took on new roles and responsibilities in the twenty-first century is the Council of Ulama. Aceh's Ulama Council is the oldest state-affiliated body of its kind in Indonesia, dating to 1965 . Since its inception it has served to actively promote the New Order's emerging developmentalist ideals, proclaiming that these were in accordance with proper understandings of Islam. In its current form, the Acehnese Council of Ulama (Majelis Permusyawaratan Ulama/M PU)

18 These particular concerns and goals of the current Shari'a system are in fact not unprecedented impositions by the Indonesian central government, but actually reflect earlier attempts of certain segments of Aceh's Islamic leadership to advance an agenda of prescriptive social reform through the modern legislative apparatus of the state dating back to draft legislation of the 1960 . 
was established through Regional Regulation (PerDa) 3/200o, and strengthened by the 2006 Law on Governing Aceh (LOGA). The Ulama Council is given, at least on paper, a very powerful position in the new legal order of Acehnese society. It is designated by law to be an equal partner with the provincial government and supposed to be deeply involved in the processes of conceptualizing and drafting legislation. The MPU is likewise invested with the right to issue fatwas (legal opinions) - whether solicited or not - on matters of government, development, economy and social development. To date, however, the MPU has been unable to exercise many of these powers and in fact, has faced some considerable obstacles in terms of internal tensions, competition with other institutions, and public ambivalence to some of its pronouncements.

Of the new institutions established under Aceh's state Shari'a system, the most often discussed (and highly contested) has been the 'Shari'a Police' (Wilayatul Hisbah/WH). The wH was first created through the enactment of Regional Regulation No. 5/2000, and further defined in sections of Qanun No. 11/ 2002, where its officers are invested with the authority to 'reprimand' (I. tegur) and 'advise' (I. nasehat) those caught violating the Shari'a as defined by Acehnese qanun. The wH does not, however, have the authority to formally charge or detain alleged offenders and thus must work together with the civil police and the public prosecutor's office in order to bring a case to the Islamic Courts. In principle the $\mathrm{WH}$ can be constituted and deployed at all levels of provincial administration down to that of the village (Ac. gampong) level. This kind of reach has, however, proven impossible to achieve due to the chronic and acute shortage of resources allocated to them. To cope with their manifest inability to handle the enforcement of Aceh's Shari'a laws on their own, the wH have developed modes of cooperation with village level officials (Ac. geuchik; imeum meunasah) and with adat institutions within the model of 'community policing.'

This solution has, however, presented another set of problems along a slippery slope, running from village justice toward vengeful vigilantism-particularly in cases perceived as offenses against the 'honour' of the local community. Over the past decade, the excessively zealous application of humiliating and at times violent punishments by both spontaneous mobs of village men and more organized bands of vigilantes - some comprised of students from Islamic schools (Ac. santridayah) - have made news headlines and filled the air of coffee shops in many parts of Aceh. ${ }^{19}$ Such incidents often attract unfavourable attention to the official state apparatus of the $\mathrm{WH}$ as well, not all of which

19 On vigilantism in contemporary Aceh, see Kloos (2014); Mahdi Syihab (2010). 
is un-deserved. ${ }^{20}$ The vocal public criticism directed most visibly toward the wH-both for its own actions and through their popular association with both other state institutions and unofficial agents for the enforcement of public morality-is discussed in detail in the chapters by Benjamin and Jan Michiel Otto, and by Reza Idria in this volume.

Before the supervision of the wH was transferred to the authority of the civilian police force (I. Satpol) in 2008, the WH was under the administration of another new institution of Aceh's Islamic legal system, the State Shari'a Agency (Dinas Syariat Islam/DSI). The DSI is structured into four main sections, of which only one is primarily involved with activity in the formal legal sphere. Most of the Agency's work is directed toward the promotion of religious and social agendas that extend well beyond the drafting and enforcement of blackletter law. This is particularly evident in the Agency's more active unit for 'Propagation and Religious Practice' (I. dakwah dan peribadatan). This unit is tasked with administering $d a^{i} w a$ programs, providing facilities for ritual observance, providing and maintaining houses of worship, facilitating the work of other religious institutions, and generally promoting the public observance and symbolism of Islam (I. Syiar).

The express intention of the Agency's work in these areas is to use the instruments of the new Islamic legal system to bring about sweeping changes in both the regulation of society and the character of individual Muslims. The concern with $d a^{c} w a$ is, in fact, seen as central to the work of the Agency, as repeatedly stressed in the formal statements and voluminous publications of the DsI's founding director, Alyasa Abubakar. As he put it, the primary goal of the state Shari'a project in Aceh is one of improving and perfecting the Islam of individual Muslims. He argues that if this is accomplished, the Acehnese as a whole will become more "honest, frugal, studious, diligent, loyal, intelligent, and emotionally mature" (Alyasa 2005, 1-5). As one of the primary architects of Aceh's contemporary Shari'a system, Alyasa elaborates the aspirations for this project of social engineering, through Islamic law in terms of an all-encompassing system regulating every aspect of both individual and social life (Alyasa 2005, 21-26). This ideal is popularly expressed in Aceh, and elsewhere across Indonesia as 'Islam yang kaffah.'21 This phrase also appears prominently in the official

20 One of the most horrific cases of this involved the gang rape of a woman by three wH officers after being taken into custody in Langsa in January 2010. "Oknum wH Mesum Harus Dihukum," Rakyat Aceh (21 April 2007): 11.

21 This Indonesian-language phrase draws on the Qur'anic verse (al-baqara/2: 208) that calls for believers to 'fully' or 'completely' (kaffah) embrace Islam (Ar. udkhulu fi'-Islam kaffatan). 
'Clarification' (Penjelasan) of Qanun 11, and has become a central referent in the public discourse associated with programs promoting the further Islamization of law in contemporary Aceh. In Alyasa's own writing, the term is used frequently to refer to a comprehensive system regulating all aspects of individual and social life, including the necessary role of official state structures in remaking Acehnese society through the implementation of Shari ${ }^{\top}{ }^{22}$

\section{Shari'a and the Limits of the State}

This 'top-down' perspective may appear to at least have the advantage of moving along what is viewed by many as the primary trajectory of modernizing religious reform, which since the late nineteenth century has been seen as increasingly one of rationalized systematization and social activism. Christopher Bayly, in his monumental study The Birth of the Modern World, has synthesized a vast body of work on the history of religions, arguing that all across the globe during the modern period processes of modernization have not undermined or eliminated religion, but rather facilitated the rise of a 'new style' for its expression in the public sphere. He thus claims that since the nineteenth century, religious reformers in many parts of the world have increasingly drawn "on rationalistic traditions and philosophies which had long been present in their respective religious traditions," to sharpen and clarify their identities while "expanding 'down' into particular societies by imposing uniformity" (Bayly 2004, 328-333). Such vectors of modernization have come to be identified as important dynamics within diverse religious traditions, thereby expanding the Weberian paradigm well beyond his famous Christian example into what has been a fruitful line of research in Islamic Studies. Ideas about 'Protestant Islam' have been discussed as significant factors in the modern transformations of Islamic practice in many parts of the world. ${ }^{23}$ Such developments are, however, still only part of the story of the complex realities of lived experience in diverse Muslim societies.

\footnotetext{
22 It pervades much of the text of the $400+$ page 'official' treatise on the subject authored by him (Alyasa 2005).

23 In discussing modern trends in this direction in Subsaharan Africa, for example, Roman Loimeier writes, "Even if we do not accept the idea that there is something like an 'Islamic Reformation,' it is quite obvious that we are witness to a 'second Islamization' of Subsaharan Muslim societies which is expressed, in particular, in social terms." (Loimeier 2005, 249).
} 
Indeed, the view that processes of modernization have inevitably lead to the dominance of rationalizing religious reform and systematization, has more recently begun to be called into question by historians. In his ground-breaking study of the diversity of religious movements in a 'modernizing' colonial port city of India, Nile Green calls for a reframing of such perspectives on modernizing religious reform, arguing that, "While an English-educated comprador class demanded a 'Protestant' Islam of scripture and sobriety, the workers in their warehouses sought a religion of carnival holidays and practical little miracles" (Green 2011, 23). He thus highlights the importance of simultaneously keeping in view the diverse range of developments in religious practice that may contradict "familiar trajectories of socio-historical development" (Green 2011, 11). In fact, he argues that during the late nineteenth and early twentieth centuries, processes of modernization actually "encouraged the creation of an ever-increasing diversity of religious producers and consumers, with the latter made more demanding through their exposure to a growing marketplace of religious products and services" (Green 2011, 10). ${ }^{24}$ Green's call for careful consideration of the "multiplicity of religious competitors" that emerge even in the face of powerful movements for totalizing systematization, is as important for students of contemporary Muslim societies as it is for historians of the nineteenth and twentieth centuries (Green 2011, 241).

Taking into account such countervailing tendencies within the complex processes of religious and social change can help us refine our understanding of developments in Aceh and elsewhere in the Muslim world that have attracted attention because of large-scale programs of religious redefinition over recent years. For example, processes of technocratic religious reform have been gaining ground in neighbouring Malaysia for decades, and over that time they have progressed a considerable way toward transforming dominant understandings of Islam there. Michael Peletz has characterized these developments as "extremely dislocating and otherwise deeply painful for rural Malays and all ordinary Muslims," and he has sought to explain, "why ordinary Malays are not inclined to resist [...] even though many proponents of rationalization, particularly dakwah people, have targeted beliefs, practices, and values long central to their (ordinary Malays') cultural identities" (Peletz 2002, 274, 196-197). Peletz sees any potential resistance constrained by a range of factors including the grave political risk of challenging the hegemony of the dakwah movement as

24 Well beyond Bombay, nineteenth-century print technology facilitated developments along diverse trajectories of Muslim religious traditions, including "a proliferation of images of saints" (Elias 2012, 38). 
the state exercises the right "to define all alternative discourses as [...] an affront to the dignity of Malays and/or Islam," as well as a pervasive sense of surveillance and social forms of what he calls "invisible censorship" (Peletz 2002, 232235). Similar factors have also been at work to some degree in Aceh. However there are other, less deterministic and state-focused ways to read the development of projects for 'Islamization' in contemporary Muslim societies that can help us to better appreciate the contexts of, and limitations upon, programs of state-directed religious reform.

In his ethnography of the Chitral community in Northwest Pakistan, Magnus Marsden has argued "against simplistic formulations treating local Islam as inherently vulnerable to global trends and forces in contemporary Islam" (Marsden 2005, 9). He does this by emphasizing the ways in which Chitral Muslims critically engage with processes of Islamization to provide a clearer picture of how Muslims in that particular context, "think, consider, reflect and exercise independent judgment in matters of faith, and how far they are uncritically deferential to men of religious authority on these issues" (Marsden 2005, 1112). The energized public sphere of post-conflict, post-tsunami Aceh provides a very different, but nonetheless equally clear case of the complexity of internal Muslim discourse that demonstrates the limits of "sweeping accounts of the wave of global Islamic revival" (Marsden 2005, 251).

In Aceh, despite state support of Islamist institutions and their role in the transformation of Acehnese Muslim belief and practice, broad reformist trends are often tempered with concessions to select forms of established local practice. This is the case, for example, with the litany of prayers for the deceased known locally as the Samadiyya. Despite being suspect in the eyes of many modernist reformers, this particular form of traditionalist ritual recitation is explicitly endorsed in the official State Shari'a Agency's handbook for villagelevel religious leaders (imeum meunasah), who are expected to lead the funerary observances of which it is a part (Suhaidy 2007, 135). Samadiyya recitations draw on (and indeed take their name from) Quranic verse and thus have, in some sense, a foundation in scripture. ${ }^{25}$ At the same time, however, the Samadiyya also involve contested conceptions of the transfer of merit to the deceased and interactions with disembodied spirits. ${ }^{26}$ In his work on such traditions in the Gayo highlands of Central Aceh, John Bowen showed that these

25 The name of the practice itself clearly indexes a rare Arabic term (al-Samad) that appears prominently in one of the most oft-recited sections of the Qur'an (al-Ikhlas/112.2).

26 Samadiyya recitations are often performed in connection with Muslim funerary rites (I. kenduri kematian) in which some practitioners see the ritual reading of this text as a means to 'open a bridge' for the spirits of the dead. 
rituals have been sharply criticised by 'Modernist' reformers for much of the twentieth century (Bowen 1993, 259-272). In a more recent study of analogous Muslim rituals for the dead in Kluet (South Aceh), however, Sehat Ihsan has also reported that local Muhammadiyah activists have come to admit 'defeat' in their attempts to put an end to such practices, in the greater interests of peace and mutual welfare (Sehat Ihsan Shadiqin 2010, 271).

While opposition to rationalizing reform agendas has served to constrain the ambitions of some modernizing reformers, not all proponents of projects for transforming Islamic belief and practice in the region have become thus resigned - particularly those with a stronger involvement with the role of state institutions in Aceh's Islamic legal system. The continuing back and forth between advocates of State Sharica (as an instrument of reform) and others in Aceh (with different views on the role of religion in society) takes place within a context in which the very categories of 'religion' and 'politics' have been configured within processes of secularizing modernization, that have shaped developments in many post-colonial Muslim societies. ${ }^{27}$ Here it is important to note that speaking of secularization in this sense does not entail a diminishing of the importance of religion in the lives of individuals. ${ }^{28}$ Rather the idea of secularization here can be seen in a more limited way-referring, as Martin Riesebrodt has expressed it, "to the process of institutional differentiation through which secular spheres - that is social spheres free of religious premises and normsemerge." It refers, in other words, to "a transformation of social orders, namely to the process of freeing social institutions from religious control" (Riesebrodt 2010, 175-177).

In her recent study of Islamism in Pakistan, Humeira Iqtidar has followed the work of Talal Asad (2003) in re-conceptualizing the secular not in terms of "a one time separation of religion and the state but as the continuous management of religious thought and practice by the state" (Iqtidar 2011, 21). Such topdown dynamics of official interventions into the definition of religious thought and practice are also clearly seen in Aceh, where the management of religion is likewise framed by the institutions of a modern nation-state. Iqtidar also draws upon the idea of Islamism as 'an agent of secularization' developed by

\footnotetext{
27 Academic definitions of what secularization is, have been myriad, but much current debate engages with the seminal work of Talal Asad (2003) and Charles Taylor (2007). See also Scott and Hirschkind (2006).

28 In fact, Riesebrodt has emphasized, 'religion' can (and in many modern contexts does) come to take on increasing importance with relation to a now more clearly delineated and autonomous 'religious sphere' within a broader 'secularized' system. See Riesebrodt $(2010,177)$.
} 
Olivier Roy (1994) to demonstrate that the rationalization and objectification of religion characteristic of secularization processes facilitate the increasing importance of individual choice, and consequently of competition between advocates of different models of proper Islamic religious thought and practice (Iqtidar 2011, 22-23). As such a situation develops, she argues, "Religious practice can no longer be a matter of the communal following of norms; it has been changed into a largely individualized decision that must be justified internally, that is, within a subject and, externally, to others around the subject" (Iqtidar 2011,157 ). All this has the effect of significantly raising the stakes on efforts to "get Islam right" on the levels of both the individual and society- thus potentially also exacerbating tensions between projects for standardizing systematization and individuating processes involved in the construction of modern subjects. The ways in which such complex negotiations of the relationships between individuals, religious leaders, and the state are managed in contemporary Aceh are insightfully explored here in the chapters by Annemarie Samuels and David Kloos.

In such contexts, I would argue, we might use case studies from Aceh to interrogate issues of importance to discussions well beyond the borders of that Indonesian province. In the dramatic contexts of the post-disaster/postconflict period, Aceh's state Shari'a system was energized by totalizing rhetorics of 'reconstruction' that were aggressively promoted by internal relief and development agencies and served to ratchet up the rhetoric of literally building a "new Aceh." With these heightened aspirations in mind, however, the results of their efforts at social transformation through the implementation of Islamic law have come to be seen by many proponents of state Shari'a in Aceh as disappointing. ${ }^{29}$ In voicing their frustration over this, mention is often made of such contingencies as fluctuations of political support, funding issues, and the training and management of personnel. These problems, while considerable, remain conceptualized as basically issues that could potentially be resolved by increased resources and better technical administration. If, however, we were to accept Iqtidar's argument that the modern state plays a central role in animating the very social processes that configure religion as a matter of individual decision, then it would appear that the realization of establishing hegemonic command over defining and regulating religion by the coercive apparatus of the modern state would be not just difficult, but ultimately impossible. Indeed, in this sense the very 'secularizing' framework of the modern state, may fun-

29 On the disappointment with the government's performance in implementing Sharica, and on the need to further develop siyasa see, for example Adan $(2008,30-34)$. 
damentally compromise the ability for it to be used as an instrument for the promotion of a totalizing program for the uniform transformation of the religious belief and practice of its citizens. It thus becomes clear that even in a context in which the intent of using Shari'a as a tool of social engineering is explicitly announced and energetically promoted, it remains crucial for us to contextualize the aspirations and accomplishments of such a project in relation to diverse aspects of Islamic belief and practice that persist and evolve well beyond the limits of the state's power to define them.

This, however, is not to say that the efforts of Aceh's proponents of state Shari'a have not accomplished anything over the past decade. For even if the goal of establishing a totalizing vision of Islam for the province may be by definition unattainable, they have made measurable progress toward pushing the parameters for defining acceptable Islamic thought and practice in the directions that they deemed desirable. These developments are often commented upon anecdotally with reference to, for example, the changing public profile of Sufi devotionalism and changing patterns of everyday dress. The papers written for this volume, however, go beyond this to provide a rich array of ethnographic material through which to explore the complexities of Islam in contemporary Acehnese society in more nuanced ways, including co-optation, confrontation, avoidance, and ambivalence.

The chapters that follow present windows onto the ways in which the rapid changes that have marked the post-disaster/post-conflict period in Aceh have not only served to facilitate the engagement of local Muslims with modern projects of democratization, gender equality, economic development, and state Shari'a, but also alternative forms of Islamic ideas and institutions with deeper roots historical in Aceh. In his chapter, David Kloos emphasizes the crucial point that even in the context of contemporary Aceh's dramatic social transformations, there are "strong currents of continuity at work in the ways in which Acehnese lead their daily lives." The volume as a whole thus aims to highlight the complex interactions between elements of continuity and change to provide a richer sense of the lived realities of Muslims in contemporary Aceh and their individual imaginations and experiences of Islam beyond the limits of the state.

\section{References}

Adan, Hasanuddin Yusuf. 2008. Syariat Islam di Aceh: Antara Implementasi dan Diskriminasi. Banda Aceh: Adnin Foundation.

Alfian, Teuku Ibrahim. 2006. "Aceh and the Holy War (Prang Sabil)." In Verandah of 
Violence: The Background to the Aceh Problem, edited by Anthony Reid, 109-120. Singapore: National University of Singapore Press.

Alyasa Abubakar. 2005. Sekilas Syariat Islam di Aceh. Banda Aceh: Dinas Syariat Islam. Analiansyah and Jamhuri. 2008. Syariat Islam Di Nanggroe Aceh Darussalam: Inventarisasi Dokumen. Banda Aceh: Dinas Syariat Islam Provinsi Nanggroe Aceh Darussalam.

Asad, Talal. 2003. Formations of the Secular: Christianity, Islam, Modernity. Stanford: Stanford University Press.

Aspinall, Edward. 2009. Islam and Nation: Separatist Rebellion in Aceh, Indonesia. Stanford: Stanford University Press.

Bayly, Christopher A. 2004. The Birth of the Modern World, 1780-1914. Malden, Mass: Blackwell Publishing.

Bowen, John. 1993. Muslims through Discourse: Religion and Ritual in Gayo Society. Princeton: Princeton University Press.

Bruinessen, Martin van. 1992. Tarekat Naqsyabandiyah di Indonesia. Bandung: Mizan. 2007. "After the Days of Abû Qubays: Indonesian Transformations of the Naqshbandiyya-Khâlidiyya," Journal of the History of Sufism 5:225-251.

Daly, Patrick, R. Michael Feener, and Anthony Reid, eds. 2012. From the Ground Up: Perspectives on Post-tsunami, and Post-conflict Aceh. Singapore: ISEAs Press.

Damsté, H.T. 1928. "Hikajat Prang Sabi." Bijdragen tot de Taal-, Land- en Volkenkunde 84:545-6o9.

Dijk, C. van. 1981. Rebellion under the Banner of Islam: The Darul Islam in Indonesia. Leiden: KITLV Press.

Elias, Jamal J. 2012. Aisha's Cushion: Religious Art, Perception, and Practice in Islam. Cambridge, Mass.: Harvard University Press.

Feener, R. Michael. 2011. "The Acehnese Past and its Present State of Study." In Mapping the Acehnese Past, edited by R. Michael Feener, Patrick Daly, and Anthony Reid, 1-24. Leiden: KITLV Press.

- 2013. Shari'a and Social Engineering: The Implementation of Islamic Law in Contemporary Aceh, Indonesia. Oxford: Oxford University Press.

- 2015. "Abd al-Samad in Arabia: The Yemeni Years of a Shaykh from Sumatra," Southeast Asian Studies 4(2):259-277.

Feener, R. Michael and Mark Cammack, eds. 2007. Islamic Law in Contemporary Indonesia: Ideas and Institutions. Cambridge, Mass.: Harvard University Press.

Feener, R. Michael, Patrick Daly, and Anthony Reid, eds. 2011. Mapping the Acehnese Past. Leiden: KITLV Press.

Feith, Herbert. 1962. The Decline of Constitutional Democracy in Indonesia. Ithaca: Cornell University Press.

Formichi, Chiara. 2012. Islam and the Making of the Nation: Kartosuwiryo and Political Islam in Twentieth-Century Indonesia. Leiden: KITLV Press. 
Green, Nile. 2011. Bombay Islam: The Religious Economy of the West Indian Ocean, 18401915. Cambridge: Cambridge University Press.

Hadi, Amirul. 2011. "Exploring Acehnese Understandings of Jihad: A Study of the Hikayat Prang Sabi." In Mapping the Acehnese Past, edited by R. Michael Feener, Patrick Daly, \& Anthony Reid, 183-198. Leiden: KITLV press.

Hefner, Robert W. 1993. "Islam, State, and Civil Society: ICMI and the Struggle for the Indonesian Middle Class." Indonesia 56:1-36.

Iqtidar, Humeira. 2011. Secularizing Islamists? Jama'at-e-Islami andJama'at-ud-Da'wa in Urban Pakistan. Chicago: University of Chicago Press.

Ito, Takeshi. 1984. "The World of the Adat Aceh: A Historical Study of the Sultanate of Aceh." PhD diss., Australian National University.

Kloos, David. 2014. "In the Name of Syariah? Vigilante Violence, Territoriality, and Moral Authority in Aceh, Indonesia," Indonesia 98:59-90.

Koto, Alaiddin. 1997. Pemikiran Politik Perti (Persatuan Tarbiyah Islamiyah), 1945-1970. Jakarta: Nimas Multima.

Kraus, Werner. 1990. "Some Notes on the Introduction of the Naqshbandiyya-Khalidiyya into Indonesia." In Naqshbandis: Cheminements et Situation Actuelle d'un Order Mystique Musulman, edited by M. Gaborieau, A. Popovic and T. Zarcone, 691-706. Istanbul and Paris: Éd. Isis.

Lau, Martin. 2006. The Role of Islam in the Legal System of Pakistan. Leiden: Martinus Nijhoff Publisher.

- 2008. "Legal Reconstruction and Islamic Law in Afghanistan." In The Law Applied: Contextualizing the Islamic Sharia, A Volume in Honor of Frank E. Vogel, edited by Peri Bearman, Wolfhart Heinrichs, and Bernard Weiss, 216-234. New York: I.B. Tauris.

Layish, A. and G.R. Warburg. 2002. The Reinstatement of Islamic Law in Sudan Under Numayri: An Evaluation of a Legal Experiment in the Light of Its Historical Context, Methodology, and Repercussions. Leiden: E.J. Brill.

Lindsey, Tim and M.B. Hooker, with Ross Clarke and Jeremy Kingsley. 2007. "Shari'a Revival in Aceh." In Islamic Law in Contemporary Indonesia: Ideas and Institutions, edited by R. Michael Feener and Mark E. Cammack, 216-254. Cambridge, Mass: Harvard University Press.

Loimeier, Roman. 2005. "Is there Something like a 'Protestant Islam'?" Die Welt des Islams 45(2):216-264.

Lombard, Denys. 1967. Le Sultanat D'Atjeh au Temps D'Iskandar Muda 1607-1636. Paris: Ecole Francaise D'Extreme-Orient.

Marsden, Magnus. 2005. Living Islam: Muslim Religious Experience in Pakistan's NorthWest Frontier. Cambridge: Cambridge University Press.

McDougall, John James. 1979. "The Technocrat's Ideology of Modernity." In What is Modern Indonesian Culture? Edited by Gloria Davis, 232-248. Athens, Ohio: Ohio University Center for International Studies. 
Miller, Michelle Ann and R. Michael Feener. 2010. "Emergency and Islamic Law in Aceh." In Emergency Powers in Asia: Exploring the Limits of Legality, edited by Victor Ramraj and Arun Thiruvengadam, 213-236. Cambridge: Cambridge University Press.

Nur Ichwan, Moch. 2007. "The Politics of Shari'atization: Central Governmental and Regional Discourses of Sharīa implementation in Aceh." In Islamic Law in Contemporary Indonesia: Ideas and Institutions, edited by R. Michael Feener and Mark E. Cammack, 193-215. Cambridge, Mass.: Harvard University Press.

Ostien, Philip, Jamila Nasir, and Franz Kogelmann eds. 2005. Comparative Perspectives on Shariah in Nigeria. Ibadan: Spectrum Books Limited.

Otto, Jan Michiel, ed. 2010. Sharia Incorporated: A Comparative Overview of the Legal Systems of Twelve Muslim Countries in Past and Present. Leiden: Leiden University Press.

Peletz, Michael G. 2002. Islamic Modern: Religious Courts and Cultural Politics in Malaysia. Princeton: Princeton University Press.

Platzdasch, Bernhard. 2009. Islamism in Indonesia: Politics in the Emerging Democracy. Singapore: ISEAs Press.

Reid, Anthony. 1979. The blood of the People: Revolution and the End of Traditional Rule in Northern Sumatra. Oxford: Oxford University Press.

Riesebrodt, Martin. 2010. The Promise of Salvation: A Theory of Religion. Chicago: University of Chicago Press.

Roy, Olivier. 1994. The Failure of Political Islam. Cambridge, Mass.: Harvard University Press.

Samuels, Annemarie. 2012. "After the Tsunami: The Remaking of Everyday Life in Banda Aceh, Indonesia." PhD diss., Leiden University.

Schlegel, Stuart A. 1979. "Technocrats in a Muslim Society: Symbolic Community in Aceh." In What is Modern Indonesian Culture? Edited by Gloria Davis, 232-248. Athens, Ohio: Ohio University Center for International Studies.

Scott, David and Charles Hirschkind, eds. 2006. Powers of the Secular Modern: Talal Asad and his Interlocutors. Stanford: Stanford University Press.

Scott, James. 1999. Seeing Like a State: How Certain Schemes to Improve the Human Condition Have Failed. New Haven and London: Yale University Press.

Sehat Ihsan Shadiqin. 2010. "Kenduri Kematian di Kluet Aceh Selatan: Pemaknaan yang Beraneka Ragam." In Serambi Mekkah yang Berubah: Views from Within, edited by Arskal Salim and Adlin Sila, 253-284. Jakarta: Pustaka Alvabet and Aceh Research Training Institute.

Shiraishi, Saya. 1975. Aceh under the Japanese Occupation: Rival Leaders in Aceh Besar and Pidie. Tokyo: Tokyo International Christian University.

Siegel, James. 1969. The Rope of God. Berkeley: University of California Press.

Snouck Hurgronje, Christiaan. 1906. The Achehnese (2 vols.). Leiden: E.J. Brill.

Suhaidy, Saleh. 2007. Buku Pegangan Teungku Imeum Meunasah. Banda Aceh: Dinas Syariat Islam Provinsi Nanggroe Aceh Darussalam. 
Syihab, Mahdi. 2010. "Penegakan Syariat: Etnografi Aksi Razia Santri Dayah di Aceh Utara." In Serambi Mekkah yang Berubah: Views from Within, edited by Arskal Salim and Adnin Sila, 57-91. Jakarta: Pustaka Alvabet and Aceh Research Training Institute.

Taylor, Charles. 2007. A Secular Age. Cambridge, Mass.: The Belknap Press of Harvard University Press.

Vogel, Frank. 2000. Islamic Law and Legal System: Studies of Saudi Arabia. Leiden: E.J. Brill. 